\title{
The incidence of acute oxaliplatin-induced neuropathy and its impact on treatment in the first cycle: a systematic review
}

\author{
Endale Gebreegziabher Gebremedhn ${ }^{1 *}$ (D) Peter John Shortland ${ }^{2}$ and David Anthony Mahns ${ }^{1}$
}

\begin{abstract}
Background: Although acute oxaliplatin-induced neuropathy (OXIPN) is frequently regarded to be transient, recent studies have reported prolongation of infusion times, dose reduction and treatment cessation following the first dose of oxaliplatin in quarter of patients. Acute OXIPN is also a well-established risk factor for chronic neuropathy. However, there is underreporting of these parameters during the acute phase ( $\leq 14$ days). This paper systematically reviews the incidence of acute OXIPN and its impact on treatment in the first cycle.

Methods: A systematic literature search was performed using PubMed and Medline. Published original articles were included if they described details about prevalence of oxaliplatin-induced acute neuropathy.

Results: Fourteen studies, comprised of 6211 patients were evaluated. The majority of patients were treated with oxaliplatin in combination with leucovorin and fluorouracil (FOLFOX). Most studies used the National Cancer Institute Common Toxicity Criteria to assess acute neuropathy. Acute neuropathy (Grades 1-4) was the most common event with prevalence ranging from 4-98\%, followed by haematological (1.4-81\%) and gastrointestinal (1.2-67\%) toxicities, respectively. Drug regimens, starting dose of oxaliplatin and neuropathy assessment tools varied across studies. In addition, moderate to severe toxicities were common in patients that received a large dose of oxaliplatin $\left(>85 \mathrm{mg} / \mathrm{m}^{2}\right)$ and/ or combined drugs. The majority of studies did not report the factors affecting acute neuropathy namely the range (minimal) doses required to evoke acute neuropathy, patient and clinical risk factors. In addition, there was no systematic reporting of the number of patients subjected to prolonged infusion, dose reduction, treatment delay and treatment cessation during the acute phase.

Conclusion: Despite the heterogeneity of studies regarding oxaliplatin starting dose, drug regimen, neuropathy assessment tools and study design, a large number of patients developed acute neuropathy. To develop a better preventive and therapeutic guideline for acute/chronic neuropathy, a prospective study should be conducted in a large cohort of patients in relation to drug regimen, starting/ranges (minimal) of doses producing acute neuropathy, treatment compliance, patient and clinical risk factors using a standardised neuropathy assessment tool.
\end{abstract}

Keywords: Colorectal cancer, Oxaliplatin, Acute neuropathy, Chronic neuropathy

\footnotetext{
* Correspondence: G.GEBREMEDHN@westernsydney.edu.au

'School of Medicine, Western Sydney University, Locked Bag 1797, Penrith

NSW, Sydney 2751, Australia

Full list of author information is available at the end of the article
} 


\section{Background}

Globally, colorectal cancer (CRC) is a major public health problem $[1,2]$. CRC is the third most common cancer in men and the second in women worldwide and the incidence is rising in many countries [3]. Surgery is the main curative therapy for stage II and III colorectal cancer. However, surgery alone results in a low 5 year disease-free survival rate [4] with half of the patients either having metastases at the time of presentation, or developing them during the course of disease $[1,5]$. In this context oxaliplatin, a third generation platinum compound has remained the backbone in the treatment of colorectal cancer both in the adjuvant and in metastatic settings [6-8]. As a single agent oxaliplatin has a 5 year disease free survival rate of $10 \%$ to $20 \%$ [9-11], when combined with fluorouracil and leucovorin (FOLFOX), a progression-disease free state was observed in $58 \%$ of patients [12-15] and a 5 year disease free survival rate of $78 \%$ [7].

The side effects of oxaliplatin infusion can limit patient compliance during cancer treatment. Whilst oxaliplatin has small but notable renal, haematological and gastrointestinal toxicities [16], the emergence of cold-induced (or cold-exaggerated) neuropathic pain like symptoms during and immediately following the first treatment in $65-98 \%$ of patients predisposes this group to increasingly severe neuropathy in the subsequent cycles [17-20]. Likewise, Attal et al., have shown that the duration of cold- (and touch-) evoked pain experienced during the first three cycles were associated with the extent of chronic pain experienced one year later [21]. Studies focused on CRC have recognised acute neuropathy as a well- established risk factor for developing a persistent change in nerve function or neuropathy [17, 19, 22-27].

With recent studies demonstrating that acute neuropathy results in prolonged infusion times [in $22 \%$ of patients: 17,25 ], treatment delay [in $2 \%$ of patients: 25], dose reduction [in $14.5 \%$ patients: 25,28 ], treatment cessation [in $6-21 \%$ of patients: $25,28,29,30$, 31 ] and functional impairment in $43 \%$ patients [25]. It is surprising that the majority of reviews remain focused on the emergence of persistent neuropathy [e.g., 32]. Despite the large negative impact of acute neuropathy on chemotherapy $[17,25,28-32]$, there is limited reporting of the factors affecting the occurrence and severity of acute neuropathy such as the starting/ the range (or minimal) doses required to evoke an acute neuropathy; numbers of patients need prolonged infusion time, dose reduction, treatment delay and treatment cessation during the acute phase $(<14$ days). The current review focuses on the prevalence of acute oxaliplatin- induced neuropathy within the first treatment cycle (between start of infusion and day 14) among colorectal cancer patients treated with oxaliplatin as a monotherapy and/ or in combination with other anti-cancer drugs.

\section{Methods}

Data sources and search strategy

A systematic search of the literature databases of PubMed and Medline was performed using key terms 'Colorectal Cancer, 'Oxaliplatin', 'Neurotoxicity', 'Oxaliplatin- Induced Acute Neuropathy' and OxaliplatinInduced Chronic Neuropathy'; commenced on 13/11/ 2016. In order to minimise the loss of relevant references all identified articles were checked for other relevant publications.

\section{Study selection criteria}

Published studies that fulfilled the following criteria were included if: (1). Oxaliplatin-induced acute toxicity was assessed among cancer patients treated with oxaliplatin between the start of infusion and day 14, (2) information about oxaliplatin treatment was available (e.g. treatment schedule, starting dose, dose modification criteria, treatment compliance), (3) empirical data papers, (4) published in peer-reviewed journals and (5) written in English. Editorials, poster abstracts, reviews, preventive strategies and therapeutic studies were excluded. The inclusion and exclusion criteria were applied to the initial 289 studies published between 1992-2016 (Fig. 1). Fourteen articles met inclusion criteria were included in this review $[8,11,14,15,17,25,29,32-38]$.

\section{Quality assessment of studies}

Studies were quality assessed based on a scoring criterion points system adapted from a published paper [39] (see Table 1). Each item of a selected study that met the criteria received one point. If an item did not fulfil the criteria, it scored no points and the data is presented in Fig. 2 as a cumulative score. Consistent with prior criteria [39] (and as indicated by the horizontal lines in Fig. 2) studies were deemed of high quality if they scored greater than $75 \%$ of the maximum achievable score $(\geq 10 / 14)$. Studies of adequate quality achieved a score between $50 \%-75 \%$ (7-9 points), and studies with a score $<7$ points were classified as low quality [39]. In the current study, two additional criteria were added (see Table 1, criteria 13 and 14) to specifically assess the impact of acute neuropathy on treatment compliance in the first 14 days (Table 1 ).

\section{Statistical analysis}

Descriptive statistics were employed to calculate the incidence of acute oxaliplatin-induced neuropathy. 


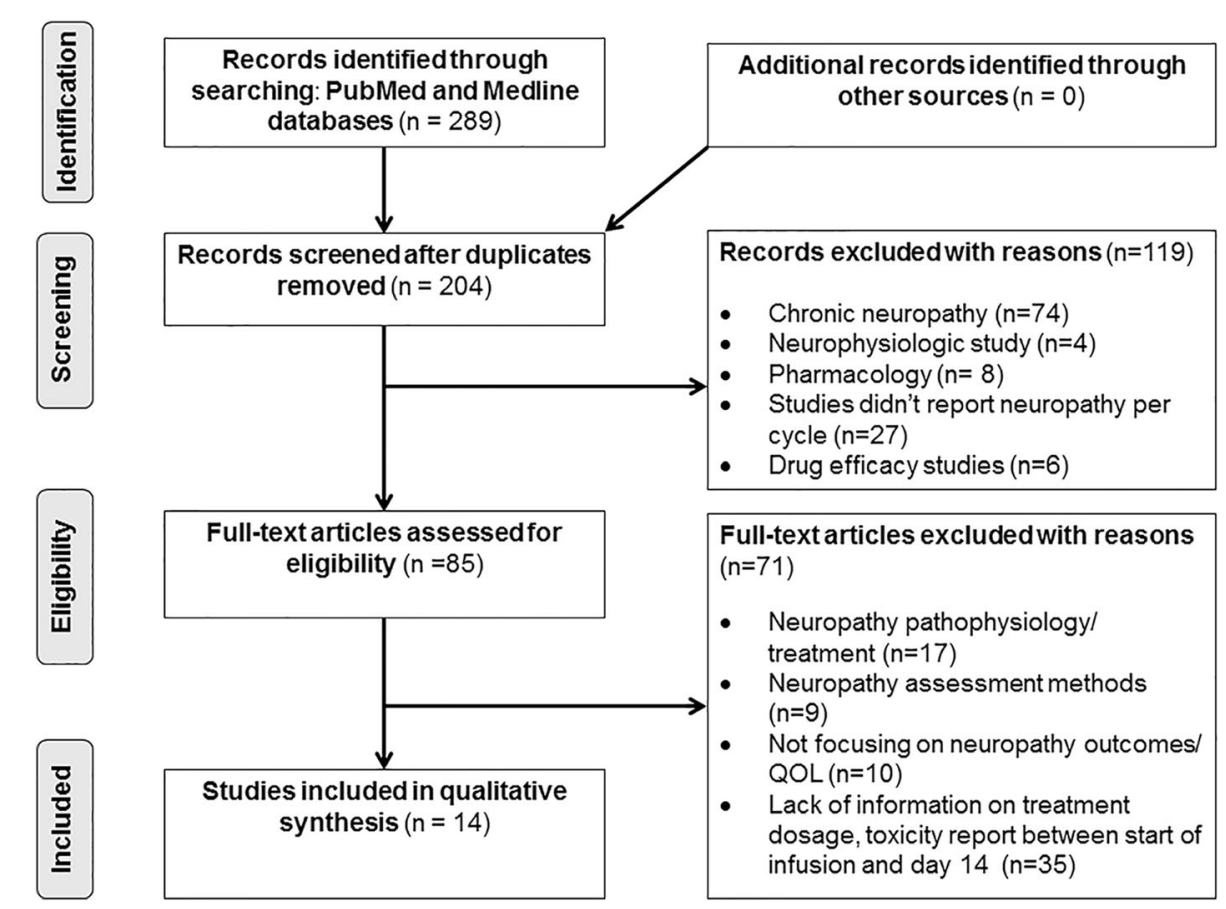

Fig. 1 PRISMA flow diagram of included and excluded studies

\section{Results}

\section{Study characteristics}

Fourteen studies published between 1992 and 2013 were included in this review (Table 2). Study designs were prospective phase-II trials [11, 14, 15, 29, 33-35], prospective phase-III trials [36, 37], prospective follow-up studies $[17,32,38]$ and one retrospective cross-sectional study [25]. Their quality scores ranged from $8-12$ points (Table 2, Fig. 2). Twelve studies were ranked high quality $[11,14,15,17,25,32-37]$, whereas two studies were considered to be medium quality $[29,38]$.

The number of patients treated with oxaliplatin in individual studies ranged from 25-2887 patients [11, 36]. The stage of cancer for those patients treated with oxaliplatin was described only in two studies [36, 37]. Oxaliplatin was administered in combination with fluorouracil (5-FU) and leucovorin/folinic acid (LV/FA) as FOLFOX regimen $[8,14,15,17,29,32,33,36,38]$. Moreover, combination therapy with capecitabine (Xeloda, a DNA inhibitor) as XELOX regimen was given in four studies [25, 29, 34, 37]. Oxaliplatin monotherapy was administered in one study [11], and the exact doses of each drug in the regimen (FOLFOX/XELOX) were not included in one study [32], (Table 2).

Acute oxaliplatin-induced toxicity was evaluated using several different tools. The National Cancer InstituteCommon Toxicity Criteria (NCI-CTC) was the most commonly used tool for the assessment of acute neuropathy $[8,11,14,25,29,34,37]$ followed by the World
Health Organization (WHO) Toxicity Criteria [15, 33, 38], Neuropathy was also assessed using NCI-CTC plus nerve conduction study (NCS) [17], NCI-CTC plus Oxaliplatin Specific Neuropathy Scale (OSNS) [35], Functional Assessment of Cancer Therapy (FACT) plus OSNS [36] and NCI-CTC plus Clinical Total Neuropathy Score (TNSc) [32] (Tables 3 and 4).

\section{Acute oxaliplatin-induced neuropathy}

The incidence of acute neuropathy varied across studies from a low of $4 \%$ to a high of $98 \%$. This is likely to be due to differences in the starting doses of oxaliplatin, differing drug combinations and dosing intervals (Table 3 and Fig. 3). However, no study examined the range (or minimal) dose required to evoke an acute neuropathy; rather they relied on a fixed dose regimen. Notably, even when the starting dose was at its lowest $\left(25 \mathrm{mg} / \mathrm{m}^{2}\right)$, $58 \%$ of patients developed grades 1-2 acute paraesthesia in the fingers and toes [15]. Moderate to severe acute oxaliplatin induced neuropathy symptoms (grades 2-4) were very common in patients who were given large starting dose of oxaliplatin $\left(>85 \mathrm{mg} / \mathrm{m}^{2}\right)[25,37]$, occurring within $24 \mathrm{~h}$ of treatment initiation. Consequently, dose modification criteria for the reduction and treatment of toxicity after starting the therapy were incorporated in the majority of studies $[8,11,14,17,25,29,32$, $34-38]$, but were not explained in two studies $[15,33]$ (Table 3). Only one study reported the number of patients who received reduced doses, or needed 
Table 1 Assessment criteria for methodological quality of studies

\begin{tabular}{l} 
Study scoring criteria \\
\hline Measures for outcome: \\
1. Assessment tool used for oxaliplatin-induced toxicity is described \\
2. A description of oxaliplatin administration given (regimen, dose \\
modification criteria) \\
3. Acute neuropathy assessment is described \\
Study population: \\
4. A description of baseline variables at least two is included (age, sex, \\
cancer, stage) \\
5. Inclusion and exclusion criteria are described \\
6. Time of acute oxaliplatin-induced toxicity measurement and number \\
of patients assessed are described between the initiation of infusion and \\
day 14 . \\
7. Information is given about study subject selection process criteria \\
Study design: \\
8. The study sample size is described \\
9. The data is prospectively gathered \\
10. The process of data collection is described \\
Results: \\
11. Acute toxicities are described \\
12. The cycle at which acute toxicity occurred is described \\
13. The number of patients who needed prolonged infusion and/ or \\
dose modification due to acute toxicity described. \\
14. The number of patients who needed treatment delay and/ or \\
cessation due to acute toxicity reported. \\
\hline Cita modfed from 39
\end{tabular}

Criteria modified from [39]

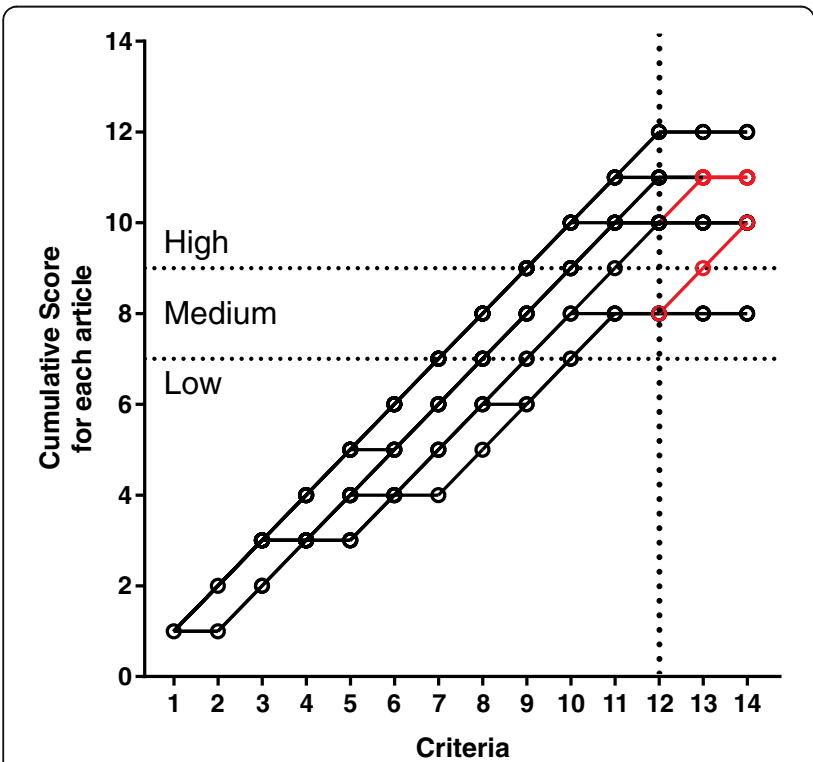

Fig. 2 Individual plot of quality assessment for reviewed studies. Each study was initially assessed against 12 previously used criterial [39]. In the current study two additional criteria (criteria 13 and 14, as per Table 1) were included in order to assess the impact of acute neuropathy on treatment compliance in the first 14 days. The cumulative scores for successive criterion in each study are joined by a connecting line; based on the final cumulative score (criterion 14) studies were deemed to be of low $(<7)$, medium (7-9) and high quality $(\geq 10)$. The addition two criteria revealed that only 2 of the 14 (highlighted in red) studies documented the impact of acute neuropathy in the first 14 days on treatment treatment delay or dropped out due to acute neuropathy [25] (Table 3).

\section{Haematological and gastro-intestinal side effects}

Oxalipaltin treatment caused haematological toxicity in $1.4-81 \%$ patients $[14,29,35]$ and gastrointestinal toxicity in $1.2-67 \%$ patients $[8,14,29,35,37]$ respectively (Table 4). Patients treated with XELOX developed grade $3 / 4$ diarrhoea on day one [37]. In a prospective, multicenter phase II study that evaluated the efficacy and safety of oxaliplatin combined with the Nordic bolus schedule of fluorouracil (5-FU) and folinic acid (FA) as first-line treatment in metastatic CRC, acute allergic reaction occurred in $1 \%(1 / 85)$, grade 4 leukopenia in $1 \%$ $(1 / 85)$ and stomatitis in $1 \%(1 / 85)$ patients respectively [35]. Likewise, in another study, patients developed grade 1 leukopenia, grade 1 thrombocytopenia and grade1 anemia, grade 1 stomatitis and gradel diarrhoea respectively [17]. In addition, in a prospective phase II study, grade 4 neutropenia and graded 3 stomatitis occurred in $1.4 \%(1 / 70)$ and $1.4 \%(1 / 70)$ patients respectively [29] (Table 4).

\section{Discussion}

Acute OXIPN occurs in the majority of patients treated with oxaliplatin and is considered to be a transient event that resolves in the first cycle [17]. However, recent studies have shown that a large number of patients continue to experience acute neuropathic pain like symptoms that tend to be more severe in cycle 2 and follow the same pattern in the remaining cycles $[8,32,40]$. Moreover, we have emphasised the impact of acute neuropathy on dose regimens, namely that the emergence of oxaliplatin-induced acute neuropathy caused prolongation of infusion times in $12-22 \%$ patients [17, $25,32]$, and/ or dose reduction in $15-43 \%$ patients [ 25 , 28 ], and/or treatment cessation in $6-21.4 \%$ patients [25, $28,30,31]$ with functional impairment in $43 \%$ of patients [25].

This review focused on factors that affect the occurrence and severity of acute neuropathy such as treatment regimen, dose reduction criteria, starting/ the range (minimal) doses of oxaliplatin required to evoke an acute neuropathy, patient related and clinical risk factors. We also assessed the number of patients where prolonged infusion time, dose reduction, treatment delay and treatment cessation were implemented, and neuropathy assessment tool. Even though the majority of studies described the type of drug regimen and starting dose of each drug in the treatment regimens, no single study reported the actual dose (i.e. how much of the starting dose was received by the patient) that caused acute toxicity during the acute phase. Notably, the lowest dosing 
Table $\mathbf{2}$ Characteristics and methodological quality of studies

\begin{tabular}{|c|c|c|c|c|}
\hline Study author & $\begin{array}{l}\text { Patients treated } \\
\text { with oxaliplatin (n) }\end{array}$ & Study design & Oxaliplatin treatment schedule/regimen & Study quality score \\
\hline Andre [14] & 97 & Prospective & $\begin{array}{l}\text { FOLFOX3 or FOLFOX } 4\left(85 \mathrm{mg} / \mathrm{m}^{2} \text { as a } 2 \mathrm{~h} \text { infusion day } 1 \text {, repeated every }\right. \\
2 \text { weeks) }\end{array}$ & 11 \\
\hline Argyriou [17] & 170 & Prospective & $\begin{array}{l}\text { FOLFOX } 4 \text { (Oxaliplatin: } 85 \mathrm{mg} / \mathrm{m}^{2} \text { as a } 2 \mathrm{~h} \text { infusion on day } 1 \text {, repeated every } \\
2 \text { weeks) }\end{array}$ & 11 \\
\hline Argyriou [32] & 150 & Prospective & FOLFOX/XELOX (OX dose) $=$ NR & 11 \\
\hline Davidov [38] & 26 & Prospective & $\begin{array}{l}\text { FOLFOX (Oxaliplatin: } 85 \mathrm{mg} / \mathrm{m}^{2} \text { as a } 2 \mathrm{~h} \text { infusion on day } 1 \text {, repeated every } \\
\text { two weeks). }\end{array}$ & 8 \\
\hline $\begin{array}{l}\text { Diaz-Rubio } \\
{[11]}\end{array}$ & 25 & Prospective & $\begin{array}{l}\text { Oxaliplatin ( } 130 \mathrm{mg} / \mathrm{m}^{2} \text { as a } 2 \text { hour infusion on day } 1 \text {, repeated every } 3 \\
\text { weeks) }\end{array}$ & 10 \\
\hline Land [36] & $395 / 2492$ & Prospective & $\begin{array}{l}\text { FOLFOX (Oxaliplatin: } 85 \mathrm{mg} / \mathrm{m}^{2} \mathrm{IV} \text { infusion on day } 1 \text { of week } 1,3 \text { and } 5 \text { of } \\
\text { each } 8 \text { week cycle for three cycles) }\end{array}$ & 10 \\
\hline Levi [15] & 93 & Prospective & FOLFOX ( 25 mg/m²/day infusion for 5 days, repeated every 3 weeks) & 12 \\
\hline Pfeiffer [29] & 70 & Prospective & $\begin{array}{l}\text { XELOX (Oxaliplatin: } 130 \mathrm{mg} / \mathrm{m}^{2} \text { as a } 30 \mathrm{~min} \text { infusion on day } 1 \text {, repeated } \\
\text { every } 3 \text { weeks) }\end{array}$ & 8 \\
\hline Ravaioli [33] & 45 & Prospective & $\begin{array}{l}\text { FOLFOX (Oxaliplatin: } 130 \mathrm{mg} / \mathrm{m}^{2} \text { as a } 2 \mathrm{~h} \text { infusion day } 1 \text {, repeated every } \\
3 \text { weeks) }\end{array}$ & 12 \\
\hline Rothenberg [8] & 463 & Prospective & $\begin{array}{l}\text { Oxaliplatin ( } 85 \mathrm{mg} / \mathrm{m}^{2} \text { as a } 2 \mathrm{~h} \text { infusion on day } 1 \text {, repeated every } 2 \text { weeks) } \\
\text { and FOLFOX ( } 85 \mathrm{mg} / \mathrm{m}^{2} \text { as a } 2 \mathrm{~h} \text { infusion on day } 1 \text {, repeated every } 2 \text { weeks) }\end{array}$ & 11 \\
\hline Schmoll [37] & 1864 & Prospective & $\begin{array}{l}\text { XELOX (Oxaliplatin: } 130 \mathrm{mg} / \mathrm{m}^{2} \text { as a } 2 \mathrm{~h} \text { infusion on day } 1 \text {, repeated every } \\
3 \text { weeks) }\end{array}$ & 10 \\
\hline Shields [34] & 48 & Prospective & $\begin{array}{l}\text { XELOX (Oxaliplatin: } 130 \mathrm{mg} / \mathrm{m}^{2} \text { as a } 2 \mathrm{~h} \text { infusion on day } 1 \text {, repeated every } \\
3 \text { week) }\end{array}$ & 11 \\
\hline Sorbye [35] & 85 & Prospective & $\begin{array}{l}\text { FOLFOX (Oxaliplatin: } 85 \mathrm{mg} / \mathrm{m}^{2} \text { as a } 2 \mathrm{~h} \text { infusion day } 1 \text {, repeated every } \\
2 \text { weeks) }\end{array}$ & 10 \\
\hline Storey [25] & 188 & Retrospective & $\begin{array}{l}\text { XELOX (Oxaliplatin: } 130 \mathrm{mg} / \mathrm{m}^{2} 2 \mathrm{~h} \text { infusion on day } 1 \text {, repeated every } \\
3 \text { weeks) }\end{array}$ & 10 \\
\hline
\end{tabular}

FOLFOX Folinic acid (Leucovorin); Fluorouracil; Oxaliplatin (OX), XELOX Capecitabine (Xeloda); Oxaliplatin (OX), NR Starting dose of the regimen was Not Reported

regimen $\left(25 \mathrm{mg} / \mathrm{m}^{2} /\right.$ day for five days) was associated with a low incidence (4\%) of acute neuropathy [15] compared to high dose regimens $(86 \%, 85-130 \mathrm{mg} /$ $\mathrm{m}^{2}$ on day one) [17]. Underreporting of such important parameters can result in premature treatment adjustment and negatively impacts on the clinical decision making process [17].

It is well established that the risk of developing chronic OXIPN is correlated with the treatment schedule, duration of infusion, starting dose of oxaliplatin, severity of acute toxicity, cumulative dose, patient and clinical factors [41]. While this may be repeatedly stated in many reviews [39, 42], only 9/14 studies reviewed here reported the incidence of acute neuropathy in the first cycle. Furthermore, even though most studies applied dose reduction criteria in order to limit the degree of subsequent toxicity, the number of patients who received reduced dose, treatment delay and treatment cessation due to acute neuropathy was reported in one study only [25]. The lack of a systematic, detailed approach to presentation of the number of patients who received dose reduction (and when) and dropout rates within the first cycle, means that the impact of such parameters on subsequent treatment cannot be informed by comprehensive data sets, making dose modification difficult in order to limit the development of acute and chronic neuropathies [43].

In this review, no study reported the number of patients whose symptoms resolved and those who had persistent neuropathy in the second cycle among who developed acute neuropathy in the first 14 days of chemotherapy. This will hamper preventive actions and treatment optimization at the early stage of treatment [43]. Moreover, studies differed in starting dose (duration of infusion, amount/ total dose), type of combination of drugs in each regimen, study design, type of cancer patients (chemonaïve/ previously untreated), neuropathy assessment tool, time of assessment of toxicity after treatment initiation and result presentation (acute versus chronic, time of occurrence of toxicity, degree of severity of symptoms, and measures taken). These heterogeneities across studies could hinder the early prediction of acute neuropathy, treatment adjustment and prevention of the ongoing development of chronic neuropathy [17].

This review also observed that severe acute neuropathy and other toxicities were common in patients treated with a large single dose of oxaliplatin $(>85 \mathrm{mg} /$ 
Table 3 Dose modification criteria, acute neuropathy assessment tools and incidence of acute neuropathy

\begin{tabular}{|c|c|c|c|c|}
\hline Study author & $\begin{array}{l}\text { Starting dose } \\
\text { of oxaliplatin }\end{array}$ & Dose modification criteria & Toxicity assessment tool & Acute neurotoxicity \\
\hline$\overline{\text { Argyriou [17] }}$ & $85 \mathrm{mg} / \mathrm{m}^{2}$ & $\begin{array}{l}\text {-Oxaliplatin: } 30 \% \text { reduction for } \\
\text { persistent or temporary (at least } \\
14 \text { days) painful paresthesia, } \\
\text { dysesthesia or functional impairment } \\
\text {-Grade } 3 \text { persisted with } 30 \% \\
\text { dose reduction, OXA omitted }\end{array}$ & $\begin{array}{l}\text {-NCl-CTC V3.0 } \\
\text {-NCS }\end{array}$ & Acute neuropathy (85.9\%) \\
\hline Argyriou [32] & NR & $\begin{array}{l}\text {-Oxaliplatin: } 30 \% \text { reduction for } \\
\text { persistent or temporary (at least } \\
14 \text { days) painful paresthesia, } \\
\text { dysesthesia or functional impairment } \\
\text {-Grade } 3 \text { persisted with } 30 \% \text { dose } \\
\text { reduction, OXA omitted }\end{array}$ & $\begin{array}{l}- \text { TNSC } \\
\text {-NCI-CTC }\end{array}$ & $\begin{array}{l}\text { Acute cold induced perioral dysesthesia } \\
\text { (89.3-98.4\%) and pharyngolaryngeal } \\
\text { dysesthesia (91.7-98.3\%) }\end{array}$ \\
\hline Davidov [38] & $85 \mathrm{mg} / \mathrm{m}^{2}$ & $\begin{array}{l}\text {-Oxaliplatin: } 25 \% \text { reduction for persistent } \\
\text { paresthesia between cycles. } \\
\text { Second } 25 \% \text { reduction if no improvement. }\end{array}$ & -WHO toxicity criteria & $\begin{array}{l}\text { Acute neuropathy (58.3\%), prolonged } \\
\text { infusion (17-23.2\%), }\end{array}$ \\
\hline Diaz-Rubio [11] & $130 \mathrm{mg} / \mathrm{m}^{2}$ & $\begin{array}{l}-25 \% \text { reduction for } \mathrm{NCl} \text { grade } 3 \\
\text { neutropenia, thrombocytopenia, peripheral } \\
\text { neurotoxicity, or grade } 2 \text { renal toxicity. 50\% } \\
\text { reduction for grade } 4 \text { neutropenia, } \\
\text { thrombocytopenia or grade } 3 \text { renal toxicity }\end{array}$ & $\begin{array}{l}\text {-NCI-CTC (National } \\
\text { Cancer Institute Common } \\
\text { Toxicity Criteria) criteria }\end{array}$ & $\begin{array}{l}\text { Laryngopharyngeal dysesthesia, and } \\
\text { severe dyspnea } 1(4 \%)\end{array}$ \\
\hline Land [36] & $85 \mathrm{mg} / \mathrm{m}^{2}$ & $\begin{array}{l}\text {-Oxaliplatin: dose reduced for grade } 2 \text { toxicity } \\
\text { persisted b/n cycles or any grade } 3 \text { toxicity. } \\
\text { Dose termination: persistent grade } 3 \text { or } \\
\text { grade } 4 \text { toxicity }\end{array}$ & $\begin{array}{l}\text {-FACT (Functional } \\
\text { Assessment of Cancer } \\
\text { Therapy) } \\
\text {-OSNS (Oxaliplatin Specific } \\
\text { Neurotoxicity Scale) }\end{array}$ & Acute neurotoxicity (68\%) \\
\hline Levi [15] & $25 \mathrm{mg} / \mathrm{m}^{2}$ & NR & $\begin{array}{l}\text {-WHO haematological, skin, } \\
\text { mucosal, \& hair toxicity. } \\
\text { Symptomatic neurological } \\
\text { toxicity grading }\end{array}$ & $\begin{array}{l}\text { Paresthesia of finger and toes in cycle } \\
\text { Grade } 1-2(58 \%)\end{array}$ \\
\hline Ravaioli [33] & $130 \mathrm{mg} / \mathrm{m}^{2}$ & NR & -WHO toxicity criteria used & Acute neuropathy (20\%) \\
\hline Rothenberg [8] & $85 \mathrm{mg} / \mathrm{m}^{2}$ & $\begin{array}{l}\text {-Dose of oxaliplatin reduced } \\
\text { by } 24 \% \text { for grade } 3 / 4 \text { febrile } \\
\text { neutropenia, thrombocytopenia, } \\
\text { nausea vomiting, diarrhoea and } \\
\text { grade } 4 \text { stomatitis. Discontinue } \\
\text { for grade } 3 / 4 \text { allergic reaction. }\end{array}$ & $-\mathrm{NCl}-\mathrm{CTC}$ V2.0 & $\begin{array}{l}\text { Acute, cold-sensitive paresthesias: all } \\
\text { grades }(58 \%) \& \text { grades 3-4: (7\%) }\end{array}$ \\
\hline Schmoll [37] & $130 \mathrm{mg} / \mathrm{m}^{2}$ & $\begin{array}{l}\text {-Oxaliplatin: } 23 \% \text { reduction for } \\
\text { grade } 3 / 4 \text { nausea or vomiting, } \\
\text { grade } 4 \text { stomatitis, and for } \\
\text { paresthesias with pain or } \\
\text { functional impairment lasting } \\
\text { for more than } 7 \text { days, or } \\
\text { paresthesias with pain persisting } \\
\text { between cycles }\end{array}$ & $-\mathrm{NCl}-\mathrm{CTC}$ v3.0 & Grades 2-4 neuropathy on day one. \\
\hline Storey [25] & $130 \mathrm{mg} / \mathrm{m}^{2}$ & $\begin{array}{l}\text {-Oxaliplatin: Infusion prolonged } \\
\text { for } 4 \text { or } 6 \mathrm{~h} \text { after acute, jelly } \\
\text { legs, pseudolaryngospasm and } \\
\text { severe laryngeal dysaesthesia. }\end{array}$ & -NCl-CTC v3.0 & $\begin{array}{l}\text { Acute neuropathy (94\%), prolonged } \\
\text { infusion }(22 \%) \text {, dose reduction }(14.5 \%) \text {, } \\
\text { treatment delay ( } 2 \%) \text {, treatment cessation } \\
(13 \%) \& \text { function impairment function } \\
\text { /grade2-4 (43\%) }\end{array}$ \\
\hline
\end{tabular}

WHO World Health Organization, NCI-CTC National Cancer Institute- Common Toxicity Criteria, TNSC Clinical Version of Total Neuropathy Score, NCS Nerve Conduction Study, NR Not reported

$\mathrm{m}^{2}$ ) and/or combined drugs in the treatment regimens. As the incidence of neuropathy observed when oxaliplatin was given alone, or in combination, were overlapping, it is difficult to ascertain whether the degree of neuropathy was due to synergetic drug effects, and this requires more studies that systematically document the emergence of neuropathy in cycle 1 ( $\leq 14$ days). In a phase III trial that compared XELOX with bolus FULV as adjuvant therapy for stage III CRC with a starting dose of oxaliplatin $130 \mathrm{mg} / \mathrm{m}^{2}$, capecitabine $1000 \mathrm{mg} /$ $\mathrm{m}^{2}$, leucovorin $500 \mathrm{mg} / \mathrm{m}^{2}$ and fluorouracil $500 \mathrm{mg} / \mathrm{m}^{2}$, patients developed acute grade2-4 neurotoxicity and 19\% (178 /938) experienced grade 3/4 diarrhoea [37]. In addition, in a retrospective cross-sectional study that 
Table 4 Dose modification criteria, toxicity assessment tools, haematological and gastro-intestinal side effects

\begin{tabular}{|c|c|c|c|c|c|}
\hline Study author & $\begin{array}{l}\text { Starting dose } \\
\text { of oxaliplatin }\end{array}$ & Dose modification criteria & $\begin{array}{l}\text { Toxicity } \\
\text { assessment } \\
\text { tool }\end{array}$ & Haematological toxicity & Gl toxicity \\
\hline Andre [14] & $85 \mathrm{mg} / \mathrm{m}^{2}$ & $\begin{array}{l}\text {-Oxaliplatin reduced by } 25 \% \text { for } \\
\text { grade } 3 \text { thrombocytopenia or } \\
\text { grade } 4 \text { diarrhea, and by } 50 \% \text { if } \\
\text { grade } 4 \text { thrombocytopenia }\end{array}$ & -NCl-CTC & $\begin{array}{l}\text { Grade } 4 \text { leukopenia, } \\
\text { grade } 3 \text { thrombocytopenia \& } \\
\text { grade } 3 \text { anemia }\end{array}$ & $\begin{array}{l}\text { Grade } 4 \text { stomatitis } \\
\text { and grade } 4 \\
\text { diarrhea. }\end{array}$ \\
\hline Pfeiffer [29] & $130 \mathrm{mg} / \mathrm{m}^{2}$ & $\begin{array}{l}\text {-Oxaliplatin: } 25 \% \text { reduction for } \\
\text { febrile neutropenia, grade } 4 \\
\text { thrombocytopenia or grade } 3 / 4 \mathrm{Gl} \\
\text { toxicity. Additional } 25 \% \text { reduction } \\
\text { if the above toxicity recurs. }\end{array}$ & -NCl-CTC v2.0 & $\begin{array}{l}\text { Acute grade4 neutropenia } \\
(1.4 \%)\end{array}$ & $\begin{array}{l}\text { Acute grade } 3 \\
\text { stomatitis } \\
(1.4 \%)\end{array}$ \\
\hline $\begin{array}{l}\text { Rothenberg } \\
{[8]}\end{array}$ & $85 \mathrm{mg} / \mathrm{m}^{2}$ & $\begin{array}{l}\text {-Dose of oxaliplatin reduced by } \\
24 \% \text { for grade } 3 / 4 \text { febrile } \\
\text { neutropenia, thrombocytopenia, } \\
\text { nausea vomiting, diarrhoea and } \\
\text { grade } 4 \text { stomatitis. Discontinue for } \\
\text { grade } 3 / 4 \text { allergic reaction. }\end{array}$ & -NCl-CTC v2.0 & $\begin{array}{l}\text { Anemia: all grades }=98(64 \%) \\
\text { and grades } 3-4=2(1 \%) . \\
\text { Thrombocytopenia: all grades }= \\
46(30 \%) \text { and grades } 3-4=4(3 \%) \\
\text { Neutropenia: all grades }=10(7 \%) .\end{array}$ & $\begin{array}{l}\text { - Diarrhea all grades: } \\
70(46 \%) \text { \& grades } \\
\text { 3-4: } 6(4 \%) \text {. Nausea: } \\
\text { all grades } 98 \text { (64\%) \& } \\
\text { grades 3-4: 6(4\%). } \\
\text { Vomiting: all grades } \\
=57 \text { (37\%) and } \\
\text { grades 3-4 = 6 (4\%). } \\
\text { Stomatitis: all grade } \\
=21 \text { (14\%). }\end{array}$ \\
\hline Schmoll [37] & $130 \mathrm{mg} / \mathrm{m}^{2}$ & $\begin{array}{l}\text {-Oxaliplatin: } 23 \% \text { reduction for } \\
\text { grade } 3 / 4 \text { nausea or vomiting, } \\
\text { grade } 4 \text { stomatitis, and for } \\
\text { paresthesias with pain or } f \\
\text { unctional impairment lasting for } \\
\text { more than } 7 \text { days, or paresthesias } \\
\text { with pain persisting between } \\
\text { cycles }\end{array}$ & -NCl-CTC v3.0 & Grade 3/4 neutropenia (4-20\%) & $\begin{array}{l}\text { acute grade } 3 / 4 \\
\text { diarrhea on day1 (19\%). }\end{array}$ \\
\hline Shields [34] & $130 \mathrm{mg} / \mathrm{m}^{2}$ & $\begin{array}{l}\text { Oxaliplatin: } 25 \% \text { reduction for } \\
\text { grade } 3 \text { thrombocytopenia, grade } 4 \\
\text { neutropenia mucositis \& diarrhea, } \\
\text { grade } 3 / 4 \text { emesis and paresthesia } \\
\text { persisting b/n cycles. } 40 \% \text { for } \\
\text { grade } 4 \text { thrombocytopenia and } \\
50 \% \text { for paresthesia impairing } \mathrm{f} \\
\text { unction }\end{array}$ & $-\mathrm{NCl}-\mathrm{CTC}$ v2.0 & $N R$ & Diarrhea 1 (7.7\%) \\
\hline Sorbye [35] & $85 \mathrm{mg} / \mathrm{m}^{2}$ & $\begin{array}{l}\text {-Oxaliplatin: } 25 \% \text { reduction for } \\
\text { persistent paresthesia b/n cycles. } \\
\text { Second } 25 \% \text { reduction if no } \\
\text { improvement }\end{array}$ & $\begin{array}{l}\text { - NCI-CTC v2.0 } \\
\text {-Oxaliplatin } \\
\text { specific neurotoxicity } \\
\text { scale }\end{array}$ & $\begin{array}{l}\text { Acute grade } 4 \text { leukopenia } 1 \text { (1.2\%) } \\
\text { Acute allergic reaction } 1 \text { (1.2\%) }\end{array}$ & $\begin{array}{l}\text { Acute stomatitis } 1 \\
(1.2 \%)\end{array}$ \\
\hline
\end{tabular}

NCI-CTC National Cancer Institute- Common Toxicity Criteria, NCS Nerve Conduction Study, NR Not reported

compared the incidence of acute neuropathy between XELOX and FOLFOX with a starting dose of oxaliplatin $130 \mathrm{mg} / \mathrm{m}^{2}$ and capecitabine $1000 \mathrm{mg} / \mathrm{m}^{2}$, the overall incidence of acute neuropathy in oxaliplatin treated group was $94 \%$ and $43 \%$ of patients developed grade $2-4$ neuropathy that impaired daily function [25]. In these studies, severe neuropathy and gastrointestinal adverse effects that occurred could be attributed to large doses and the combined effects of drugs in the treatment regimens.

There was also considerable variation of the assessment tool used to identify oxaliplatin- induced acute toxicity across studies, although NCI-CTC was the commonest tool employed. Therefore, a lack of standardized assessment tool will underestimate the prevalence of acute toxicity and makes comparison among studies difficult [44]. Moreover, comparing the prevalence and severity of neuropathy even using NCI-CTC is still difficult as there is a the potential for interobserver disagreement [45]. Furthermore, there is no consensus whether subjective or objective assessment methods are important to determine the severity of both acute and chronic neuropathies [39].

Given the lack of well-proven neuroprotective agents or treatment options for acute oxaliplatin induced neuropathy, it is paramount to identify risk factors $[23,46]$. Even if a potential neuro-protective treatment can be identified, the emergence of acute neuropathies during the first treatment cycle highlights the need for a preemptive intervention prior to the first dose of oxaliplatin. Whether these acute hypersensitivities, presumed to be the result of neuronal sensitisation, are mechanistically distinct from the emergence of persistent neuropathy following repeated doses of oxaliplatin cannot be 


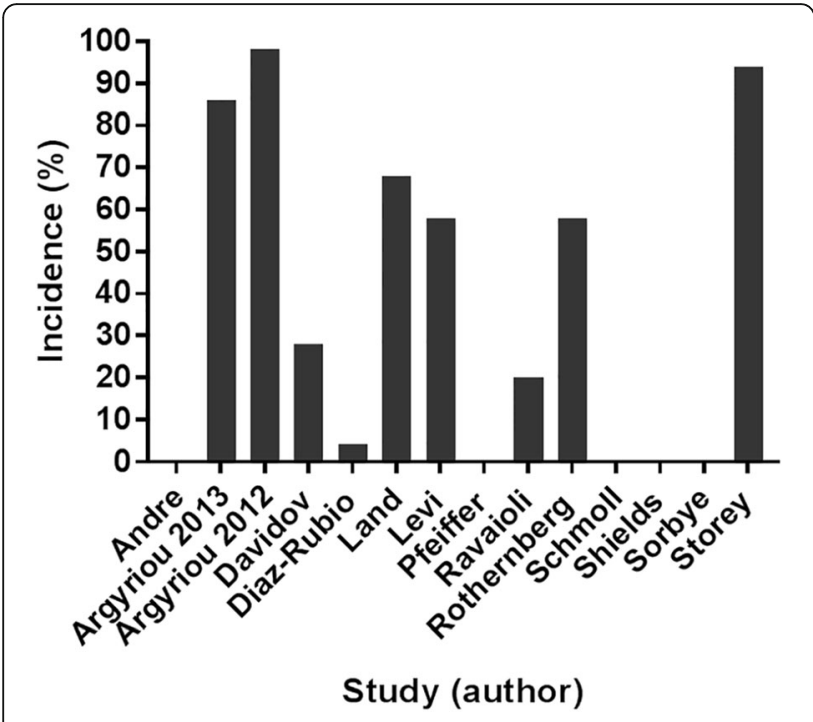

Fig. 3 Reported incidences of acute neuropathy in the first cycle ( $\leq 14$ days). Nine of 14 studies reported acute neuropathy symptoms in 4-98\% of patients. In other studies, the incidence of neuropathy was not clearly identified. One other study, neuropathy was reported as grade $2-$ 4 (percentage value was not reported) [37]

resolved with the available data. Likewise, none of the studies reviewed here discussed risk factors. Rather, some authors excluded patients with risk factors such as pre-existing peripheral neuropathy, diabetes mellitus, and alcohol abuse to avoid interference with their clinical assessment $[17,32,36]$. Oxaliplatin-induced peripheral neuropathy has a major negative impact on the quality of life of CRC patients. Therefore, it will be of great value to understand the patient and clinical related risk factors such as intensity of acute symptoms, duration of cold-evoked pain in the past, body surface area $<2.0 \mathrm{~m}^{2}$, winter-period, pre-existing neuropathy, previous or co-administered toxic chemotherapeutic drugs and diabetes mellitus [42].

Evidence shows that, oxalate, a metabolite of oxaliplatin alters the functional properties of voltage gated sodium channels in DRG neurons that leads to change in channel function causing hyperexcitability of sensory neurons [47-50]. Moreover, indirect interactions with voltage-gated sodium channels, through chelation of intracellular calcium can cause membrane hyperexcitability [26]. Acute hyperexcitability is a strong mediator or predictor of oxaliplatin induced chronic peripheral nerve damage [17]. Therefore, treating physicians may be advised to adjust the doses based on the severity of neuropathy- like symptoms and /or patients' conditions, and closely monitor patients using standardized neuropathy assessment tools to minimise the severity of acute neuropathy, improve treatment compliance and to prevent the ongoing development of chronic neuropathy. Furthermore, nerve excitability studies may provide additional objective assessment for acute neurotoxicity following the initiation of infusion and ongoing development of chronic/cumulative neurotoxicity [46, 51]. However, while these techniques have been applied in research studies this has not translated to routine clinical practice.

\section{Conclusion}

In the current review, studies varied regarding starting dose of oxaliplatin, treatment regimens, study design, acute neuropathy assessment tool and result presentation (acute versus chronic and measures taken). Despite the heterogeneity of studies, a large number of patients developed acute neuropathy, and moderate to severe toxicities were relatively common in patients received single large dose of oxaliplatin $\left(>85 \mathrm{mg} / \mathrm{m}^{2}\right)$ and combined drugs in the treatment regimens.

In addition, the majority of studies did not report the factors that affect the occurrence and severity of acute neuropathy $(<14$ days $)$ such as the minimal dose required to evoke an acute neuropathy, patient related and clinical risk factors. Likewise, there was no systematic reporting of the number of patients subjected to prolonged infusion, dose reduction, treatment delay and treatment cessation during the acute phase.

Recent studies reveal that a large number of patients continue experiencing acute neuropathic symptoms until cycle $2[8,32,40]$. The persistence of these acute neuropathic symptoms results in subsequent prolongation of infusion time, or dose reduction and/ or treatment cessation nearly in quarter of patients during the acute phase. To develop better preventive and therapeutic guideline for acute/ chronic neuropathy, a prospective study should be conducted in a large cohort of patients in relation to drug regimen, starting/ the ranges of oxaliplatin dose producing acute neuropathy, treatment compliance, patient and clinical risk factors using a standardised neuropathy assessment tool. Moreover, oncologists should monitor patients routinely during clinical assessment and use a standardised neuropathy assessment tool in order to detect acute neuropathy early, improve treatment compliance and to prevent/ameliorate the development of persistent neuropathy. Furthermore, nerve excitability tests need to be considered for patient monitoring as it may provide additional objective information for the assessment of acute hyperexcitability following the administration of oxaliplatin.

\footnotetext{
Abbreviations

FACT: Functional Assessment of Cancer Therapy; FOLFOX: Folinic Acid

(Leucovorin) (FOL), Fluorouracil (F), Oxaliplatin (Ox); NCl-CTC: National Cancer Institute- Common Toxicity Criteria; NCS: Nerve Conduction Study;

OSNS: Oxaliplatin Specific Neurotoxicity Scale; TNSc: Clinical Version of Total Neuropathy Score; XELOX: Capecitabine (Xeloda) and Oxaliplatin (OX)
}

Acknowledgments

Not applicable 


\section{Funding}

None

\section{Availability of data and materials}

The supporting materials used in this review are contained within the manuscript.

\section{Authors' contributions}

EG conducted the literature search. All authors assessed the quality of studies and equally contributed to draft the manuscript. All authors read the manuscript and agreed to publish it in BMC Cancer.

\section{Ethics approval and consent to participate}

Not applicable

\section{Consent for publication}

Not applicable

\section{Competing interests}

The authors declare that they have no competing interests.

\section{Publisher's Note}

Springer Nature remains neutral with regard to jurisdictional claims in published maps and institutional affiliations.

\section{Author details}

${ }^{1}$ School of Medicine, Western Sydney University, Locked Bag 1797, Penrith NSW, Sydney 2751, Australia. ${ }^{2}$ School of Science and Health, Western Sydney University, Locked Bag 1797, Penrith NSW, Sydney 2571, Australia.

\section{Received: 9 May 2017 Accepted: 6 March 2018}

\section{Published online: 12 April 2018}

\section{References}

1. Parkin DMBF, Ferlay J, Pisani P. Global Cancer statistics, 2002. CA Cancer J Clin. 2005;55:74-108.

2. Jemal A, Bray F, Center MM, Ferlay J, Ward E, Forman D. Global cancer statistics. CA Cancer J Clin. 2011;61(2):69-90.

3. Ferlay J, Soerjomataram I, Dikshit R, Eser S, Mathers C, Rebelo M, Parkin DM, Forman D, Bray F. Cancer incidence and mortality worldwide: sources, methods and major patterns in GLOBOCAN 2012. Int J Cancer. 2015;136(5):E359-86.

4. Gill S, Loprinzi CL, Sargent DJ, Thome SD, Alberts SR, Haller DG, Benedetti J, Francini G, Shepherd LE, Francois Seitz J, Labianca R, Chen W, Cha SS, Heldebrant MP, Goldberg RM. Pooled analysis of fluorouracil-based adjuvant therapy for stage II and III colon cancer: who benefits and by how much? J Clin Oncol. 2004;22(10):1797-806.

5. Ragnhammar PHL. A systematic overview of chemotherapy effects in colorectal cancer. Acta Oncol. 2009:40(2-3):282-308.

6. Kalofonos HP, Aravantinos G, Kosmidis P, Papakostas P, Economopoulos T, Dimopoulos M, Skarlos D, Bamias A, Pectasides D, Chalkidou S, Karina M, Koutras A, Samantas E, Bacoyiannis C, Samelis GF, Basdanis G, Kalfarentzos F, Fountzilas G. Irinotecan or oxaliplatin combined with leucovorin and 5-fluorouracil as first-line treatment in advanced colorectal cancer: a multicenter, randomized, phase II study. Ann Oncol. 2005;16(6):869-77.

7. André TBC, Mounedji-Boudiaf L, Navarro M, Tabernero J, Hickish T, Topham C, Zaninelli M, Clingan P, Bridgewater J, Tabah-Fisch I, de Gramont A. Oxaliplatin, fluorouracil, and leucovorin as adjuvant treatment for colon cancer. N Engl J Med. 2004:350:2343-51.

8. Rothenberg ML, Oza AM, Bigelow RH, Berlin JD, Marshall JL, Ramanathan RK, Hart LL, Gupta S, Garay CA, Burger BG, Le Bail N, Haller DG. Superiority of oxaliplatin and fluorouracil-leucovorin compared with either therapy alone in patients with progressive colorectal cancer after irinotecan and fluorouracil-leucovorin: interim results of a phase III trial. J Clin Oncol. 2003;21(11):2059-69.

9. Machover DD-RE, De Gramont A, Schilf A, Gastiaburu JJ, Brienza S, Itzhaki M, Metzger G, N'Daw D, Vignoud J, Abad A, Francois E, Gamelin E, Marty M, Sastre J, Seitz JE, Ychou M. Two consecutive phase II studies of oxaliplatin $(\mathrm{L}-\mathrm{OHP})$ for treatment of patients with advanced colorectal carcinoma who were resistant to previous treatment with fluoropyrimidines. Ann Oncol. 1996:7:95-8.
10. Becouarn YYM, Ducreux M, Borel C, Bertheault-Cvitkovic F, Seitz JF, Nasca S, Nguyen TD, Paillot B, Raoul JL, Duffour J, Fandi A, Dupont-Andr G, Rougier P. Phase II trial of oxaliplatin as first-line chemotherapy in metastatic colorectal cancer patients. J Clin Oncol. 1998;16(8):2739-44.

11. Diaz-Rubio ESJ, Zaniboni A, Labianca R, Cortes-Funes H, De Braud F, Boni C, Benavides M, Dallavalle G, Homerin M. Oxaliplatin as single agent in previously untreated colorectal carcinoma patients: a phase II multicentric study. Ann Oncol. 1998;9:105-8.

12. Goldberg RM, Sargent DJ, Morton RF, Fuchs CS, Ramanathan RK, Williamson SK, Findlay BP, Pitot HC, Alberts SR. A randomized controlled trial of fluorouracil plus leucovorin, irinotecan, and oxaliplatin combinations in patients with previously untreated metastatic colorectal cancer. J Clin Oncol. 2004:22(1):23-30

13. Giacchetti SPB, Zidani R, Le Bail N, Faggiuolo R, Focan C, Chollet P, Llory JF, Letourneau Y, Coudert B, Bertheaut-Cvitkovic F, Larregain-Fournier D, Rol AL, Walter S, Adam R, Misset JL, Le'vi F. Phase III multicenter randomized trial of oxaliplatin added to chronomodulated fluorouracil-leucovorin as first-line treatment of metastatic colorectal cancer. J Clin Oncol. 2000;18:136-47.

14. Andre TBK, Bouche $\mathrm{O}^{\prime}$, Bensmaine MA, Louvet C, Franc E', Lucas V, Desseigne F, Beerblock K, Bouche O', Carola E, Merrouche Y, Morvan F, Dupont-Andre G, de Gramont A. Multicenter phase II study of bimonthly high-dose leucovorin, fluorouracil infusion, and oxaliplatin for metastatic colorectal cancer resistant to the same leucovorin and fluorouracil regimen. JC Oncol. 1999;17:3560-8.

15. Livi FMJ, Brienza S, Adam R, Metzger G, Itzakhi M, Caussanel JP, Kunstlinger F, Lecouturier S, Descorps-Decle're A, Jasmin C, Bismuth H, Reinberg A. A Chronopharmacologic phase II clinical trial with 5-fluorouracil, folinic acid, and oxaliplatin using an ambulatory multichannel programmable pump. Cancer Chemother Pharmacol. 1992;69(4):893-900

16. Xu N, Fang WJ, Zhang XC, Yu LF, Bao HY, Shi GM, Huang S, Shen P. A phase II trial of oxaliplatin, folinic acid, and 5-fluorouracil (FOLFOX4) as first-line chemotherapy in advanced colorectal cancer: a China single-center experience. Cancer Investig. 2007;25(7):599-605.

17. Argyriou AA, Cavaletti G, Briani C, Velasco R, Bruna J, Campagnolo M, Alberti P, Bergamo F, Cortinovis D, Cazzaniga M, Santos C, Papadimitriou K, Kalofonos HP. Clinical pattern and associations of oxaliplatin acute neurotoxicity: a prospective study in 170 patients with colorectal cancer. Cancer. 2013;119(2):438-44.

18. Park SB, Goldstein D, Lin CS, Krishnan AV, Friedlander ML, Kiernan MC. Acute abnormalities of sensory nerve function associated with oxaliplatin-induced neurotoxicity. J Clin Oncol. 2009;27(8):1243-9.

19. Alejandro LM, Behrendt CE, Chen K, Openshaw H, Shibata S. Predicting acute and persistent neuropathy associated with oxaliplatin. Am J Clin Oncol. 2013;36(4):331-7.

20. Velasco R, Bruna J, Briani C, Argyriou AA, Cavaletti G, Alberti P, Frigeni B, Cacciavillani M, Lonardi S, Cortinovis D, Cazzaniga M, Santos C, Kalofonos HP. Early predictors of oxaliplatin-induced cumulative neuropathy in colorectal cancer patients. J Neurol Neurosurg Psychiatry. 2014;85(4):392-8.

21. Attal N, Bouhassira D, Gautron M, Vaillant JN, Mitry E, Lepere C, Rougier P, Guirimand F. Thermal hyperalgesia as a marker of oxaliplatin neurotoxicity: a prospective quantified sensory assessment study. Pain. 2009;144(3):245-52.

22. Saadati HSMW. Oxaliplatin-induced hyperexcitability syndrome in a patient with pancreatic cancer. J Pancreas. 2009:10(4):459-61.

23. Argyriou AA, Polychronopoulos P, Iconomou G, Chroni E, Kalofonos HP. A review on oxaliplatin-induced peripheral nerve damage. Cancer Treat Rev. 2008;34(4):368-77

24. Grothey A, Goldberg RM. A review of oxaliplatin and its clinical use in colorectal cancer. Expert Opin Pharmacother. 2004;5(10):2159-70.

25. Storey DJ, Sakala M, McLean CM, Phillips HA, Dawson LK, Wall LR, Fallon MT, Clive S. Capecitabine combined with oxaliplatin (CapOx) in clinical practice: how significant is peripheral neuropathy? Ann Oncol. 2010;21(8):1657-61.

26. Gamelin L, Capitain O, Morel A, Dumont A, Traore S, Anne le B, Gilles S, Boisdron-Celle M, Gamelin E. Predictive factors of oxaliplatin neurotoxicity: the involvement of the oxalate outcome pathway. Clin Cancer Res 2007; 13 (21):6359-6368

27. Part III: Pain Terms, A Current List with Definitions and Notes on Usage" (pp 209-214) Classification of Chronic Pain [ https://www.iasp-pain.org/ Education/Content.aspx?ltemNumber=1698 ]. Accessed 28 Nov 2017.

28. Loupakis F, Stein A, Ychou M, Hermann F, Salud A, Osterlund P. A review of clinical studies and practical guide for the administration of triplet 
chemotherapy regimens with bevacizumab in first-line metastatic colorectal cancer. Target Oncol. 2016;11(3):293-308.

29. Pfeiffer P, Sorbye H, Ehrsson H, Fokstuen T, Mortensen JP, Baltesgard L, Tveit KM, Ogreid D, Starkhammar H, Wallin I, Qvortrup C, Glimelius B. Short-time infusion of oxaliplatin in combination with capecitabine (XELOX30) as second-line therapy in patients with advanced colorectal cancer after failure to irinotecan and 5-fluorouracil. Ann Oncoly. 2006;17(2):252-8.

30. Pfeiffer $\mathrm{P}$, Hahn P, Anita JH. Short-time infusion of oxaliplatin (eloxatin ${ }^{\oplus}$ ) in combination with capecitabine (xeloda $\left.{ }^{\odot}\right)$ in patients with advanced colorectal cancer. Acta Oncol. 2009;42(8):832-6.

31. Yanai T, Hashimoto H, Kato K, Hamaguchi T, Yamada Y, Shimada Y, Yamamoto H. Successful rechallenge for oxaliplatin hypersensitivity reactions in patients with metastatic colorectal cancer. Anticancer Res. 2012; 32:5521-6.

32. Argyriou AA, Velasco R, Briani C, Cavaletti G, Bruna J, Alberti P, Cacciavillani M, Lonardi S, Santos C, Cortinovis D, Cazzaniga M, Kalofonos HP. Peripheral neurotoxicity of oxaliplatin in combination with 5 -fluorouracil (FOLFOX) or capecitabine (XELOX): a prospective evaluation of 150 colorectal cancer patients. Ann Oncol. 2012;23(12):3116-22.

33. Ravaioli A, Marangolo M, Pasquini E, Rossi A, Amadori D, Cruciani G, Tassinari D, Oliverio G, Giovanis P, Turci D, Zumaglini F, Nicolini M, Panzini I. Bolus fluorouracil and leucovorin with oxaliplatin as first-line treatment in metastatic colorectal cancer. J Clin Oncol. 2002;20(10):2545-50.

34. Shields AF, Zalupski MM, Marshall IL, Meropol NJ. Treatment of advanced colorectal carcinoma with oxaliplatin and capecitabine: a phase II trial. Cancer. 2004;100(3):531-7.

35. Sorbye $H$, Glimelius B, Berglund A, Fokstuen T, Tveit KM, Braendengen $M$, Ogreid D, Dahl O. Multicenter phase II study of Nordic fluorouracil and folinic acid bolus schedule combined with oxaliplatin as first-line treatment of metastatic colorectal cancer. J Clin Oncol. 2004;22(1):31-8.

36. Land SR, Kopec JA, Cecchini RS, Ganz PA, Wieand HS, Colangelo LH, Murphy K, Kuebler JP, Seay TE, Needles BM, Bearden JD 3rd, Colman LK, Lanier KS, Pajon ER Jr, Cella D, Smith RE, O'Connell MJ, Costantino JP, Wolmark N. Neurotoxicity from oxaliplatin combined with weekly bolus fluorouracil and leucovorin as surgical adjuvant chemotherapy for stage II and III colon cancer: NSABP C-07. J Clin Oncol. 2007;25(16):2205-11.

37. Schmoll HJ, Cartwright T, Tabernero J, Nowacki MP, Figer A, Maroun J, Price T, Lim R, Van Cutsem E, Park YS, McKendrick J, Topham C, Soler-Gonzalez G, de Braud F, Hill M, Sirzen F, Haller DG. Phase III trial of capecitabine plus oxaliplatin as adjuvant therapy for stage III colon cancer: a planned safety analysis in 1,864 patients. J Clin Oncol. 2007;25(1):102-9.

38. Davidov DN. Oxaliplatin/5-fluorouracil/leucovorin in the treatment of patients with metastatic colorectal cancer. Journal of IMAB - Annual Proceeding (Scientific Papers). 2013;19(3):476-80.

39. Beijers AJ, Mols F, Vreugdenhil G. A systematic review on chronic oxaliplatin-induced peripheral neuropathy and the relation with oxaliplatin administration. Support Care Cancer. 2014;22(7):1999-2007.

40. Pachman DRQR, Seisler DK, Smith EM, Beutler AS, Ta LE, Lafky JM, WagnerJohnston ND, Ruddy KJ, Dakhil S, Staff NP, Grothey A, Loprinzi CL. Clinical course of oxaliplatin-induced neuropathy: results from the randomized phase III trial N08CB (alliance). J Clin Oncol. 2015;33(30):3416-22.

41. Grothey A. Clinical management of oxaliplatin-associated neurotoxicity. Clin Colorectal Cancer. 2005;5:S38-46.

42. Pulvers JN, Marx G. Factors associated with the development and severity of oxaliplatin-induced peripheral neuropathy: a systematic review. Asia Pac J Clin Oncol. 2017;13(6):345-55.

43. Drott JE, Starkhammar H, Börjeson S, Berterö CM. Oxaliplatinilnduced neurotoxicity among patients with colorectal cancer-documentation. Open J Nurs. 2014;4:265-74.

44. Vatandoust $\mathrm{S}$, Joshi R, Pittman KB, Esterman A, Broadbridge V, Adams J, Singhal N, Yeend S, Price TJ. A descriptive study of persistent oxaliplatininduced peripheral neuropathy in patients with colorectal cancer. Support Care Cancer. 2014;22(2):513-8.

45. Postma TJHJ, Muller MJ, Ossenkoppele GJ, Vermorken JB, Aaronson NK. Pitfalls in grading severity of chemotherapy-induced peripheral neuropathy. Annuls of Oncology. 1998;9:739-44.

46. Park SB, Lin CS, Kiernan MC. Nerve excitability assessment in chemotherapyinduced neurotoxicity. J Vis Exp. 2012;62:e3439.

47. Adelsbergera HQS, Grosskreutz J, Lepier A, Eckel F, Lersch C. The chemotherapeutic oxaliplatin alters voltage-gated $\mathrm{Naq}+$ channel kinetics on rat sensory neurons. Eur J Pharmacol. 2000;406:25-32.
48. Webster RG, Brain KL, Wilson RH, Grem JL, Vincent A. Oxaliplatin induces hyperexcitability at motor and autonomic neuromuscular junctions through effects on voltage-gated sodium channels. Br J Pharmacol. 2005;146(7): 1027-39.

49. Bouhours M, Sternberg D, Davoine CS, Ferrer X, Willer JC, Fontaine B, Tabti $N$. Functional characterization and cold sensitivity of $\mathrm{T} 1313 \mathrm{~A}$, a new mutation of the skeletal muscle sodium channel causing paramyotonia congenita in humans. J Physiol. 2004;554(Pt 3):635-47.

50. SB Rutkove SB. Effects of temperature on neuromuscular electrophysiology. Muscle Nerve. 2001;24:867-82.

51. Park SB, Lin CS, Krishnan AV, Goldstein D, Friedlander ML, Kiernan MC. Oxaliplatin-induced neurotoxicity: changes in axonal excitability precede development of neuropathy. Brain. 2009;132(Pt 10):2712-23.

\section{Submit your next manuscript to BioMed Central and we will help you at every step:}

- We accept pre-submission inquiries

- Our selector tool helps you to find the most relevant journal

- We provide round the clock customer support

- Convenient online submission

- Thorough peer review

- Inclusion in PubMed and all major indexing services

- Maximum visibility for your research

Submit your manuscript at www.biomedcentral.com/submit
( Biomed Central 